\title{
KEBERDAYAAN PETANI PADI ORGANIK DALAM MEMENUHI PERMINTAAN PASAR TERSTRUKTUR (Studi Kasus Pada Kelompok Tani Sarinah Kabupaten Bandung)
}

\author{
Yayat Sukayat, Dika Supyandi \\ Program Studi Agribisnis Fakultas Pertanian UNPAD \\ Jl.Raya Jatinangor Km.21 Bandung 40600 \\ E-mail: yayatsukayat@yahoo.com
}

\begin{abstract}
ABSTRAK
Permintaan beras organik di Kabupaten Bandung terus meningkat, dari 2 ton pada tahun 2012, menjadi 20 ton pada tahun 2015. Pangsa pasar beras organik pada umumnya lapisan masyarakat kelas menengah ke atas, sehingga beras organik lebih banyak dijual di pasar terstruktur. Peningkatan permintaan tersebut direspon oleh pemerintah melalui penguatan petani dan kelembagaannya. Kelompok Tani Sarinah merupakan salah satu lembaga petani padi organik yang terus berbenah dan diberdayakan pemerintah sebagai upaya mengimbangi laju permintaan. Pada umumnya, pasar beras organik sangat memperhatikan kuantitas, kualitas, kontinuitas dan komitmen, oleh karena itu pemberdayaan petani padi organik ditekankan kepada empat hal tersebut. Pertanyaannya, bagaimana perkembangan keberdayaan petani dalam mengusahakan padi organik? Penelitian ini didesain secara kualitatif dengan metode studi kasus dan analisis etik-emik. Hasil penelitian mengungkap bahwa petani padi organik di Kelompok Tani Sarinah sudah berdaya dalam aspek teknis produksi dan membangun jejaring kerjasama. Secara ekonomi para petani sudah mampu memupuk modal sendiri dan secara psikologis sudah bisa mengikuti perkembangan pasar. Artinya petani yang berafiliasi dalam Kelompok Tani Sarinah sudah berdaya, sehingga mampu memenuhi empat kriteria yang diinginkan pasar padi organik.
\end{abstract}

Kata kunci: petani, padi organik, pasar terstruktur, keberdayaan.

\begin{abstract}
Demand for organic rice in Bandung Regency continues to increase, from 2 tons in 2012 to 20 tons in 2015. The market share of organic rice is generally middle and higj class people, so that more organic rice are sold in structured market. The increase in demand is responded by farmers and governement through farmers and its institutional strengthening. Sarinah Farmers Group is an organic rice farmers institution that continues to improve and empowered by the government to anticipate the demand. In general, the organic rice market is very concerned with quantity, quality, continuity and commitment. Therefore, organic rice farmer empowerment is emphasized to these four points. The question is, how the development of the empowered status of farmers who cultivate organic rice? This study was designed quantitatively through case study methods and analysis of ethics-emic. The results of the study reveal that the organic rice farmers in Sarinah Farmers Group has been empowered in terms of technical aspects of production and network building. Economically, the farmers have been able to cultivate their own capital and psychologically was able to follow market developments. This means that farmers who are affiliated with Sarinah Farmer Group have owned powers in order to meet the four criteria desired by organic rice market.
\end{abstract}

Keywords: farmer, organic rice, structured market, empowered.

\section{PENDAHULUAN.}

Permintaan beras dari tahun ke tahun menunjukkan peningkatan seiring dengan masih relatif tingginya $(1,99 \%)$ laju pertumbuhan penduduk (BPS, 2013). Kementerian Pertanian RI (2013) mengemukakan bahwa tingginya permintaan beras yang mencapai $139 \mathrm{~kg} / \mathrm{kapita} / \mathrm{tahun}$ telah berdampak terhadap tingginya permintaan beras yang mencapai 42,36 juta ton beras atau 70,6 juta ton padi. Fenomena permintaan akan beras tersebut, juga diikuti dan diperlihatkan dengan selektifnya konsumen terhadap kualitas beras. Perubahan selera dan meningkatnya orientasi 
kesehatan sebagai dasar penentuaan pilihan beras, permintaan terhadap beras yang bermutu, sehat dan aman mulai meningkat. Merespon dinamika pasar tersebut, Kementerian Pertanian RI dan Pemerintah Daerah Jawa Barat mulai melegalisasi komoditas dengan label sehat, aman dan bergizi, termasuk beras.

Salah satu kabupaten di Jawa Barat yang serius dan intensif dalam mengembangkan beras sehat atau yang sering disebut beras organik adalah Kabupaten Bandung. Permintaan beras organik di Kabupaten Bandung untuk memenuhi pasar domestik terbilang cukup bagus, dari tahun 2012 yang hanya 2 ton, naik menjadi 10 ton pada tahun 2013/2014, dan meningkat menjadi 20 ton pada tahun 2015 (Sukayat dkk., 2013) . Upaya percepatan pencapaian target tersebut terus dilakukan melalui pendekatan kelompok (Sukayat et al., 2014).

Penguatan petani untuk mengarah ke padi sehat ini sudah cukup lama dilakukan pemerintah, mulai dari program SLPHT (Sekolah Lapang Pengendalian Hama Terpadu) yang menekankan teknik budidaya yang memperhatikan lingkungan dengan konsep ambang batas ekonomi, dan diteruskan dengan program SRI (System of Rice Intensification) pada tahun 2000-an. Di Kabupaten Bandung, pengembangan padi sehat ini sudah cukup lama, hanya penekanan ke arah padi organik baru dilakukan sejak tahun 2010, mengikuti kabupaten Tasikmalaya, yang sudah mampu mengekspor ke berbagai negara di Asean dan Timur Tengah (Sukayat et al., 2013, 2014).

Mengingat permintaan beras sehat atau organik terus meningkat, baik untuk pasar domestik maupun internasional, pemerintah Kabupaten Bandung melalui Dinas Pertanian dan Badan Ketahanan Pangan, terus mendorong petani untuk meningkatkan kuantitas, kualitas dan kontinuitas dalam pengembangan padi organik melalui demplot dan dem area pada kelompok-kelompok tani di daerah-daerah sentra produksi padi, seperti Bojongsoang, Majalaya, Banjaran dan Soreang. Hingga tahun 2016, di Kabupaten Bandung sudah ada satu gapoktan dan lima kelompok tani yang mengembangkan padi organik, namun baru dua kelompok tani yang sudah lolos uji sertifikasi tingkat nasional, sementara yang lainnya masih dalam proses. Salah satu kelompok tani yang konsisten mengembangkan padi organik adalah Kelompok Tani Sarinah di Kecamatan Ciparay Kabupaten Bandung.
Kelompok Tani Sarinah beranggotakan petani sebanyak 32 orang, dengan luas lahan kurang lebih $12 \mathrm{Ha}$. Selama ini Kelompok Tani Sarinah memiliki pasar yang sudah relatif stabil dengan permintaan rata-rata perbulan sebanyak 15 ton. Adanya permintaan yang relatif konstan, tentu saja membuat Kelompok Tani Sarinah harus berbuat maksimal dalam meningkatkan persediaan guna memenuhi permintaan pasar. Karena secara potensial dari luas 12 ha, kelompok tani sarinah hanya mampu menyediakan GKG sebanyak 158,4 ton/tahun, atau sebanyak 95,04 ton beras pertahun, padahal permintaan mencapai 180 ton beras, artinya hanya mampu mencukupi sekitar $50 \%$ permintaan. Untuk itu Kelompok Tani Sarinah harus membangun kerjasama yang solid dengan kelompok tani lain yang sudah disertifikasi agar produksi beras baik secara kuantitas, kualitas maupun kontinuitas terjaga dalam memenuhi permintaan pasar.

Terpenuhinya pasar hanya mungkin apabila kelompok tani-kelompok tani yang berafiliasi berdaya dalam arti memiliki kemampuan dan komitmen, baik secara kelembagaan maupun secara individu sebagai anggota kelompok. Ketidakberdayaan inilah yang seringkali menjadi dasar kurang berhasilnya pengembangan agribisnis di Indonesia. Kerjasama dalam kelompok, ataupun kerjasama antar kelompok nampaknya sangat mudah untuk diungkapkan, namun kerjasama ini sangat memerlukan kehati-hatian, mengingat dalam kerjasama ada benefit yang diharapkan nyata oleh setiap komponen yang bekerjasama. Berangkat dari fenomena tersebut timbul pertanyaan, dengan terbangunnya kerjasama antar kelompok, bagaimana keberdayaan petani sebagai anggota dari kelompok tersebut.

\section{METODE PENELITIAN}

Penelitian ini menggunakan disain kualitatif dengan teknik studi kasus. Metode penelitian kualitatif dinamakan sebagai metode baru, dinamakan juga metode postpositivistik karena berlandaskan filsafat postpositivisme. Metode ini juga disebut interpretive method karena data hasil penelitian lebih berkenaan dengan interpretasi atas data yang ditemukan di lapangan (Sugiyono, 2012). Studi kasus adalah salah satu penelitian deskriptif yang objek peristiwanya pada peristiwa sekarang, hanya satu unit kasus, dapat berupa kesatuan sosial tertentu, orang seorang, satu keluarga, suatu kelompok, organisasi dalam suatu komunitas 
tertentu dan sebagainya serta penelitiannya bersifat eksploratif mendalam (Rusidi, 1993).

Data-data terkait penelitian diperoleh dari dua sumber antara lain data primer dan data sekunder. Data primer adalah informasi penelitian atau sumber bahan yang diperoleh melalui hasil observasi dan wawancara kepada informan. Data primer diperoleh dari hasil wawancara mendalam dengan para informan. Teknik penentuan informan dilakukan secara sengaja (purposive), yaitu pengurus kelompok tani Sarinah dan anggota kelompok, serta mitra kelompok tani dalam aspek pemasaran dan pengambil kebijakan sebagai regulator, berdasarkan pertimbangan bahwa orang-orang tersebut adalah informan pelengkap yang paling mengetahui informasiinformasi yang berkaitan dengan usaha Kelompok Tani Sarinah. Data sekunder adalah data yang diperoleh dari buku-buku, jurnal, dokumentasi, catatan lapangan, dan literatur dari instansi terkait sesuai dengan yang dibutuhkan oleh peneliti. Data ini juga diperoleh dari Kelompok Tani Sarinah dan sumber lain yang memungkinkan dalam pencarian data.

Kualitas data dan informasi yang ada dipengaruhi oleh teknik pengumpulan data. Teknik pengumpulan data penelitian ini dilakukan oleh peneliti dengan beberapa cara (Sugiyono, 2012). Pertama, melalui teknik observasi, yaitu pengumpulan data dengan cara mengadakan pengamatan langsung ke lokasi penelitian tepatnya di dalam lingkup usaha Kelompok Tani Sarinah. Aspek-aspek yang diteliti adalah aspek pengembangan bisnis, pengembangan kemitraan, keberdayaan petani, khususnya dalam aspek kemampuan dan komitmen petani dalam pengembangan bisnis. Kedua, wawancara mendalam, yakni wawancara dengan informan utama (pendiri dan pengurus kelompok, seluruh anggota kelompok tani, informan dari pihak pasar padi organik kelompok (pembeli perorangan dan pasar modern, dan Dinas Pertanian Tanaman Pangan Kabupaten Bandung); dan Ketiga, studi pustaka, yakni mencari dan mengumpulkan data sekunder mengenai perkembangan usahatani padi organik, perkembangan pasar padi organik, kemandirian dan keberdayaan petani, serta best practices pemberdayaan petani dengan mengkaji buku-buku, literatur-literatur, dan dokumen-dokumen yang berkaitan.

Rancangan analisis data merupakan tindakan mengolah data menjadi informasi yang bermanfaat untuk menjawab masalah penelitian. Rancangan analisis yang dipakai dalam penelitian ini adalah analisis deskriptif. Menurut Nazir (2003), metode deskriptif merupakan pencarian fakta dengan interpretasi yang tepat. Penelitian deskriptif mempelajari masalah-masalah dalam masyarakat, serta tata cara yang berlaku dalam masyarakat serta situasi-situasi tertentu, termasuk tentang hubungan, kegiatan-kegiatan, sikap-sikap, pandangan-pandangan, serta proses-proses yang sedang berlangsung dan pengaruh-pengaruh dari satu fenomena.

Berikut adalah poin-poin penting yang dideskripsikan: (1) perkembangan usaha Kelompok Tani Sarinah serta bagaimana kelompok tani berupaya memberdayakan petani anggota sekaligus mengembangkan usaha untuk pasar yang lebih luas lagi; (2) hubungan kemitraan kelompok tani dengan pihak-pihak lain terkait pengembangan usahanya. Peneliti mendeskripsikan bentuk-bentuk kemitraan yang dilakukan kelompok tani beserta pelaksanaannya; (3) kemandirian dan keberdayaan petani dalam hal kemampuan (aspek pengetahuan, keterampilan, sikap dan pengalaman petani dalam melakukan usahatani padi organik) dan komitmen (aspek kepatuhan dan ketaatan petani dalam memenuhi kesepakatan yang telah dibuat).

Pengujian keabsahan data diperoleh dengan cara triangulasi. Triangulasi merupakan teknik yang didasari pola pikir fenomenologi yang bersifat multi perspektif. Artinya untuk menarik kesimpulan yang mantap, diperlukan beberapa cara pandang dari beragam fenomena, dan selanjutnya dapat ditarik kesimpulan yang lebih mantap dan lebih bisa diterima kebenaranya. Teknik triangulasi yang digunakan adalah triangulasi dengan sumber, yang berarti mengecek balik derajat kepercayaan suatu informasi yang diperoleh melalui waktu, dana, alat yang berbeda. Hal ini digunakan dengan jalan: (1) membandingkan data hasil wawancara terhadap subjek penelitian. (informan utama) dengan data hasil wawancara dengan sumber informasi (informan) lain dalam penelitian; (2) membandingkan data hasil wawancara dengan data hasil pengamatan (observasi); (3) membandingkan data hasil wawancara dengan isi dokumen yang berkaitan dengan penelitian; dan (4) melakukan member check yaitu perbaikan jika ada kekeliruan dalam pengumpulan data/informasi atau menambah kekurangan, sehingga informasi dilaporkan sesuai dengan apa yang dimaksud informan. 


\section{PEMBAHASAN}

Kajian yang menunjuk kearah keberdayaan petani yang terafiliasi dalam suatu naungan kelembagaan pertanian berupa wujud kelompok tani, terlebih dahulu harus tergambarkan bagaimana perkembangan usaha kelompok tani yang merupakan ruang bagi individu khususnya petani dalam melakukan gerak, serta bagaimana kelompok tani melakukan pemberdayaan dan relasi soaial dengan kelompok lain guna terciptanya petani yang berdaya serta berusahatani yang berkelanjutan. McGee (2004) dalam Sukayat et al (2013) dengan teori "Space Actor and Knowledge", melihat bahwa secara sosiologis gerak dan ativitas seseorang termasuk petani sangat terkait dengan ruang waktu dan tempat. Oleh karena itu Kelompok Tani Sarinah sebagai ruang bagi petani anggota dalam beraktivitas guna pencapaian tujuan, ikut menentukan terbangunnya keberdayaan petani dalam pengembangan usahanya.

\section{Perkembangan Usaha Kelompok Tani Sarinah dan Pemberdayaan Petani Anggota dalam Menuju Pasar Terstruktur}

Secara umum kebijakan pembangunan pertanian menetapkan tiga pendekatan keterpaduan, yakni pendekatan sistem agribisnis, keterpaduan antara pembangunan pertanian dan perekonomian pedesaan secara berkelanjutan, serta pendekatan yang memperhatikan keberadaan petani, sumber daya alam, lingkungan serta pertanian wilayah. Adapun tujuan dari pembangunan itu sendiri adalah perwujudan sistem pertanian yang tangguh serta mandiri, yang pada gilirannya dapat meningkatkan kesejahteraan para petani dan keluarganya. Berangkat dari kesadaran itu pula maka Kelompok Tani Sarinah berkeinginan menghasilkan produk yang sehat, dan lingkungan yang sehat dan berkesinambungan. Menyadari bahwa tanah di hamparan sawah dalam pengelolaan Kelompok Tani Sarinah sudah tidak subur dan tidak sehat lagi (akibat pemupukan kimia yang terus menerus, mengakibatkan tanah menjadi lengket dan sulit diolah, yang berdampak pada rendahnya produksi hanya pada kisaran 4-5 ton/ha), mendorong Kelompok Tani Sarinah melakukan uji pupuk organik dengan sistem semi organik di lahan sawah seluas 5 ha, dan pada tahun 2004 pada luasan yang sama dicoba budidaya padi tanpa pupuk kimia.

Dosis pupuk organik yang digunakan setiap tahun ditambah sehingga hasil produksi semakin bertambah pula. Pada tahun 2007 hasil panen dilakukan test laboraturium di IPB Bogor dan hasil uji tidak mendeteksi zat kimia. Pada tahun yang sama berbekal dari uji laboratorium, beras sehat tanpa kandungan kimia dijual dengan harga lebih tinggi dari harga pasaran keluar daerah. Pada tahun itu pula dibentuk Kelompok "Organik Sarinah", dan kemudian dikukuhkan pada tahun 2010. Saat ini, anggota kelompok Organik Sarinah terus bertambah baik jumlah anggota maupun lahan produksi, demikian pula hasil produksinya. Pada musim tanam 2011/2012 rata-rata produksi mencapai 8,157 ton/ha, jumlah anggota 32 orang dengan luas lahan $20 \mathrm{Ha}$, dan yang telah disertifikasi seluas $13.7 \mathrm{Ha}$. Tahun berikutnya luas lahan bertambah $6.3 \mathrm{Ha}$ dan telah lulus inspeksi eksternal dan internal.

\section{Lokasi Usaha Kelompok tani}

Lokasi para petani padi yang tergabung dalam Kelompok Tani Sarinah terletak di Blok Kanduruan Desa Bumiwangi Kecamatan Ciparay Kabupaten Bandung. Lokasi usaha tersebut sangat strategis, berkat dukungan sumberdaya alam terutama pengairan yang menjamin keberhasilan budidaya padi. Usaha budidaya padi organik di Kelompok Tani Sarinah memberikan kontribusi yang sangat baik terhadap peningkatan pendapatan keluarga, karena hasil panennya dibeli dengan harga yang lebih tinggi daripada harga di pasaran dan dengan hasil produksi terus meningkat dengan kualitas gabah baik yang pada akhirnya ikut mendorong perekonomian keluarganya.

\section{Perkembangan Anggota dan Usaha Kelompok tani}

Jumlah anggota Kelompok Tani Sarinah, sejak didirikan (2007/2009) sampai dengan 2012 mengalami peningkatan yang cukup signifikan, dari 8 orang (2007/2009), 21 orang (2009/2010), 27 orang (2010), 30 orang (2010/2011), 30 orang (2011) dan 32 orang (2012). Hingga tahun 2012 jumlah petani yang berafiliasi menjadi anggota Kelompok Tani Sarinah dan sudah tersertifikasi berjumlah 32 orang (13,7 Ha). Pada awal berdiri, pemasaran hasil padi organik hanya dilakukan secara door to door dan word of mouth, atas dasar pertemanan di kantor-kantor serta melalui, pameran-pameran, selain dijual di sebuah pasar modern (Foodhall), dengan jumlah yang terjual kurang lebih 2 ton dalam kurun waktu 1 sampai dengan 2 bulan.

Seiring permintaan yang terus bertambah dari 4 ton pada tsahun 2011 menjadi 10 ton 
Tabel 1 Data Produksi Padi Organik Kelompok Tani “Organik Sarinah"

\begin{tabular}{|c|c|c|c|c|c|c|c|c|}
\hline \multirow[t]{2}{*}{ No } & \multirow[t]{2}{*}{ Tahun } & \multirow{2}{*}{$\begin{array}{l}\text { Rataan } \\
\text { Produksi }\end{array}$} & \multirow{2}{*}{$\begin{array}{l}\text { Luas } \\
\text { Lahan }\end{array}$} & \multirow{2}{*}{$\begin{array}{l}\text { Produksi } \\
\text { GKP }\end{array}$} & \multirow{2}{*}{$\begin{array}{l}\text { Beras } \\
\text { Kg. }\end{array}$} & \multirow{2}{*}{$\begin{array}{l}\text { Harga } \\
\text { Rp. } \\
\end{array}$} & \multirow{2}{*}{$\begin{array}{l}\text { Jumlah } \\
\text { Rp. }\end{array}$} & \multirow[t]{2}{*}{ Hasil Produksi } \\
\hline & & & & & & & & \\
\hline 1 & $2009 / 2010$ & 7.437 & 10 & 37.185 & $18.592,50$ & 8.000 & 148.740 .000 & Beras sehat \\
\hline 2 & 2010 & 6.370 & 15 & 63.700 & 31.850 & 10.000 & 318.500 .000 & Beras sehat \\
\hline 3 & $2010 / 2011$ & 7.234 & 18 & 130.212 & 65.106 & 10.000 & 651.060 .000 & Beras sehat \\
\hline 4 & 2011 & 6.358 & 18 & 114.444 & 57.222 & 10.000 & 572.220 .000 & Beras sehat \\
\hline \multirow[t]{4}{*}{5} & $2011 / 2012$ & 8.157 & 20 & & & & & \\
\hline & & & B.6,3 & 5138911 & 25694,55 & 10000 & 256.945 .500 & Beras sehat \\
\hline & & & A. 13,7 & 111750,9 & 55875,45 & 13.000 & 726.380 .850 & $\begin{array}{l}\text { Beras organik } \\
\text { bersertifikat }\end{array}$ \\
\hline & & & 8 & 8000 & 4800 & 13.000 & 62.400000 & Beras organik * \\
\hline
\end{tabular}

Sumber: Kelompok Tani Sarinah (2014); *) membeli dari Gapoktan Harapan Jaya.

pada tahun 2013, yaitu masuknya Nutrifood sebagai konsumen yang relatif tetap menerima pasokan dari Kelompok Tani Sarinah.

Kelompok Tani Sarinah mulai menata kekuatan untuk memenuhi permintaan pasar, salah satu upaya yang dilakukan untuk memenuhi permintaan pasar tersebut yaitu mengajukan sawah anggota Kelompok Tani Sarinah yang luasnya 2 Ha untuk disertifikasi, dan menerima pasokan gabah dari Gapoktan Harapan Jaya (sudah disertifikasi Inofice). Selain itu, pengembangan anggota kelompok mulai melibatkan kelompok tani lain yaitu kelompok "Udi" seluas $4 \mathrm{Ha}$ dengan 4 orang anggota, dan $15 \mathrm{Ha}$ (9 orang) kelompok tani di kawasan Rancamanuk, namun keduanya gagal sertifikasi, yang disebabkan oleh ketidakmampuan (tidak berdaya) petani menahan kebiasaan untuk menggunakan bahan kimia. Sebagai contoh, di kelompok Udi yang membersihkan pematang dengan menggunakan pembasmi gulma, dan Kelompok Rancamanuk menggunakan pestisida dalam membasmi hama, walaupun dalam pemupukannya sudah menggunakan pupuk organik.

Pada Tahun 2014/2015 permintaan beras organik dari Kelompok Tani Sarinah, terus meningkat menjadi 15 ton/bulan, bahkan di ahir 2016 permintaan menjadi 35 ton perbulan. Semua belum terpenuhi, hingga saat ini baru mampu memasok 10 ton/bulan. Untuk itu Kelompok Tani Sarinah bekerja sama dan membina kelompok tani "Agi” sebanyak 12 orang petani (20 Ha) untuk disertifikasi bersamaan dengan sebagian lahan Kelompok tani Sarinah $(6,3 \mathrm{Ha})$ yang dikelola oleh 4 orang anggota Kelompok Tani Sarinah. Dengan demikian, di tahun 2016 jumlah petani yang berafiliasi kedalam Kelompok Tani Sarinah menjadi 48 orang atau $45 \mathrm{Ha}$, dan pada bulan Februari 2017, diharapkan kelompok tani di Rancamanuk yang luasnya $15 \mathrm{Ha}$ (9 orang) lolos tersertifikasi, sehingga luas keseluruhan menjadi 60 Ha, diluar Gapoktan Harapan Jaya (8 Ha).

Kelompok Tani Sarinah memfasilitasi seluruh proses sertifikasi, sejak dari penyediaan pupuk organik, obat pembasmi hama dan penyakit, dan benih yang akan digunakan. Adanya kepastian pasar dengan harga yang relatif stabil menjadi stimulan bagi kelompok tani lain untuk berafiliasi kedalam Kelompok Tani Sarinah.

\section{Hubungan Kemitraan Kelompok Tani dalam Pengembangan Usaha}

Untuk mengembangkan keberdayaan kelompok, kerjasama dalam kelompok dan antar kelompok serta kerjasama dengan kelembagaan lain merupakan suatu keharusan. Kerjasama antar individu dan atau antar kelembagaan merupakan konsep dasar kemitraan. Dalam kerjasama ini setiap yang terlibat akan menunjukkan adanya pembagian tugas sesuai status dan peranannya, serta didukung oleh adanya kesetaraan dan transparansi.

Kelompok Tani Sarinah sebagai

kelompok tani yang bergerak dalam pengembangan padi organik, melakukan berbagai terobosan dalam menjaga keberlanjutan usahanya. Salah satu bentuk terobosan yang dikembangkan yaitu menjalin kerjasama (kemitraan) dengan kelompok tani lain dan dengan perusahaan yang bergerak di bidang pangan. Misalnya dengan Foodhall di Jakarta dan di Medan, serta dengan Nutrifood. Pola kemitraan yang dibangun antara Kelompok Tani Sarinah mengikuti pola dagang umum, dimana Kelompok Tani Sarinah memasok ke Pasar terstruktur (Foodhall dan Nutrifood), dan pasar terstruktur memasarkannya.

Berbeda dengan hubungan antara Kelompok Tani Sarinah dengan pasar 
terstruktur, hubungan antara Kelompok Tani Sarinah dengan kelompok tani lainnya dilengkapi dengan kesepakatan kontrak bersama, baik yang terkait dengan volume, harga, mutu dan waktu. Selain dari pada itu Kelompok Tani Sarinah pun membantu kelompok tani mitra terkait dengan sarana produksi, dan pensertikasian melalui Inofice. Pola tersebut dinamakan pola subkontrak.

Kemandirian dan keberdayaan petani diukur melalui sejumlah indikator yakni: (a) kemampuan, meliputi aspek pengetahuan, keterampilan, sikap dan pengalaman petani dalam melakukan usahatani padi organik; (b) komitmen, meliputi aspek kepatuhan dan ketaatan petani dalam memenuhi kesepakatan yang telah dibuat.. Keberdayaan dan kemandirian petani anggota kelompok sangat terkait dengan usaha-usaha yang dilakukan oleh kelompok tani. Ditingkat kelompok, kemampuan yang harus dimiliki oleh para anggota kelompok yaitu kemampuan manejerial mulai dari merencanakan, pengorganisasian, pelaksanaan dan pengawasan dalam pengembangan usahatani padi organik agar usaha berjalan berkesinambungan. Selain itu kemampuan membangun jejaring yang kohesif baik di antara pelaku utama, maupun dengan pelaku usaha, bahkan dengan lembaga pelayanan (delivery system) merupakan suatu keharusan.

Dalam Kamus Besar Bahasa Indonesia, keberdayaan adalah menyangkut kemampuan dan kesanggupan, dimana kemampuan sendiri adalah kecakapan dalam bidang teknik yang bagi petani tidak perlu diragukan lagi karena itu bidang profesinya, sedangkan kesanggupan adalah kesediaan tentang janji atau komitmen. Keberdayaan itu sendiri muncul sebagai akibat adanya proses penyadaran; pengorganisasian; kaderisasi, dukungan teknis dan pengelolaan sistem. Tahapan tersebut merupakan tahapan yang harus dilakukan dalam kegiatan pemberdayaan. Pemberdayaan sendiri lebih menunjuk kepada usaha realocation of power melalui pengubahan struktur sosial (Suharto, 1997 dalam Alfitri, 2011). Artinya di dalamnya mengandung konsep kemandirian, jaringan kerja, partisipasi dan pemerataan (Alfitri, 2011). Lebih lanjut pemberdayaan sebagai suatu proses, berupaya membangun agar power yang ada pada diri petani/ masyarakat mampu digunakan untuk mencapai tujuan. Oleh karena itu dalam mengubah struktur sosial lama menuju struktur sosial yang baru, memerlukan waktu yang panjang, karena tidak semua petani/ masyarakat mampu melihat peluang yang sama, dan belum tentu memperoleh kemudahan yang sama.

Pemberdayaan melalui pendekatan kelompok merupakan upaya membangun kebersamaan dan kerjasama dalam pencapaian tujuan. Melalui pendekatan kelompok ini diharapkan dapat mengeliminir perbedaan kemampuan dalam melihat peluang dan kemudahan untuk mencapai tujuan, melalui belajar bersama, bekerja bersama dan dukungan fasilitas yang sama. Melalui pemberdayaan baik dalam penguatan individu maupun penguatan kelompok, harapannya petani pada gilirannya akan mampu mengatasi berbagai kebutuhan hidupnya dari upaya-upaya sebagai dampak adanya penguatan (petani yang mandiri dan cerdas) (Hasansulama, 2005). Keberdayaan sebagai wujud adaptasi petani dengan adanya pemberdayaan akan terungkap dari kemampuan dan kesanggupan dalam pengembangan usahanya lebih lanjut.

Tingginya kesadaran masyarakat akan hidup sehat mendorong makin selektifnya penentuan jenis makanan, salah satunya beras. Konsumsi beras mulai dilakukan menurut katagori ambang nilai sehat (relatif terbebas dari unsur kimia) yang dapat

dipertanggungjawabkan menjadi peluang besar bagi Kelompok Tani sarinah untuk meningkatkan produksi dan produktivitas padi organik. Derasnya permintaan masyarakat akan beras organik tersebut, sudah barang tentu telah menuntut kemampuan dan kesanggupan petani yang terafiliasi dalam Kelompok Tani Sarinah untuk memenuhi permintaan pasar baik secara kuantitas, kualitas, kontinuitas maupun komitmen sebagai wujud keberdayaan petani dalam pemenuhan pasar (tempat bertemunya penjual dan pembeli, atau tempat terjadinya interaksi antara penjual dan pembeli). Secara sosiologis interaksi antara penjual dan pembeli yang dibangun atas dasar komitmen baik kuantitas maupun kualitas menuju kepada kesinambungan pasar, itulah wujud dari pasar terstruktur.

Keberdayaan petani yang terorganisir dalam kelompok menuju pasar terstruktur sangat terpulang kepada dinamika pemberdayaan yang dibangun dalam menjaga keberlanjutan pasar. Kemampuan menjaga pasar dari segi jumlah (kuantitas), kualitas, maupun kontinuitas itu merupakan wujud komitmen dari oknum-oknum yang 
berinteraksi. Pemberdayaan sebagai suatu rangkaian proses yang panjang agar manusia berdaya, lebih menunjuk kepada adanya realokasi kekuatan, agar rakyat mampu berkuasa, dan tumbuh kembang dengan kekuatan sendiri (kemandirian). Wujud penguatan yang di lakukan di masyarakat pada dasarnya ditujukan dalam rangka penguatan individu (personal empowerment), penguatan komunitas (community empowerment), dan atau penguatan kelompok (group empowerment).

Ditingkat petani atau sebagai produsen padi organik, keberdayaan atau kemampuan dan kesanggupan yang harus dimilikinya yaitu mulai dari kemampuan berproduksi/teknis (dikenal dengan panca usahatani), yang selanjutnya diikuti dengan kemampuan panen dan pasca panen (keseluruhan dikenal dengan sapta usahatani); kemampuan sosial (kemampuan kerjasama membangun jejaring); kemampuan ekonomis (kemampuan dalam pemupukan modal dan membangun pasar); kemampuan psikologis (kemampuan dalam melihat relung pasar dan peluang pasar, serta kemampuan dalam menghadapi stagnasi pasar). Secara teknis, petani yang berafiliasi dalam Kelompok Tani Sarinah khususnya dalam menjalankan panca usahatani sudah berjalan baik, mulai dari pembenihan sampai dengan pengendalian hama penyakit bahkan panen dan pasca panen. Sistem pertanian organik merupakan penguatan dari cara yang dikembangkan melalui System of Rice Intensification (SRI) yang menurut FAO (2008), merupakan cara budidaya tanaman padi yang sangat memperhatikan ekosistem (tanah, air, udara, organisme makro dan mikro), sehingga menghasilkan produksi dan produktivitas yang tinggi, dan mengurangi dampak negatif terhadap lingkungan. Oleh karena itu CIIAD/Cornell International Institute Agriculture Development (2010) dalam Styger (2011) memandang bahwa SRI merupakan suatu metode dalam berusahatani, yang mengedepankan paket prinsip bukan paket teknologi. Paket prinsip tersebut bagi petani organik di Kelompok Tani Sarinah sudah merupakan keharusan yang terus dilakukan agar kualitas dan produktivitas usahatani terus meningkat. Terlebih $100 \%$ petani yang tergabung sangat menggantungkan hidupnya dari hasil usahatani pada lahan tersebut. Adanya kesadaran dan kemampuan secara teknis dalam pengembangan padi organik merupakan wujud berdayanya petani secara teknis (better farming) (Hasansulama, 2005). Prinsip-prinsip yang dilakukan oleh Petani yaitu :

\section{Persemaian}

Benih yang digunakan petani anggota

Kelompok Tani Sarinah semuanya sama yaitu jenis padi unggul (beras merah) yaitu varietas aeksibundong. Benih ini disediakan oleh ketua kelompok, dan diperoleh secara gratis. Proses persemaian yang dilakukan oleh petani yaitu diawali dengan seleksi benih, dengan cara memasukan benih ke dalam air, benih yang tenggelam merupakan benih yang baik, sedangkan benih yang mengapung merupakan benih yang tidak baik. Untuk lebih memastikan bahwa benih itu baik atau tidak, benih tadi dimasukan kembali ke dalam larutan air garam, bila benih itu tenggelam maka benih tersebut benar-benar baik. Benih yang benar-benar baik lalu direndam dalam air selama 24 jam, ditiriskan dan diperam selama 2-3 hari, kemudian disemaikan pada media tanah yang sudah dicampur kompos selama 7-12 hari, selanjutnya benih siap ditanam. Semua petani yang sudah terafiliasi di Kelompok Tani Sarinah (sebanyak 32 orang) melakukan tahapan tersebut dan mereka bukan hanya paham, tetapi tahapan itu sudah merupakan suatu keharusan yang mereka lakukan.

\section{Pengolahan Lahan}

Luas lahan yang dikelola oleh 32 orang petani totalnya mencapai 13 ha yang sudah memperoleh sertifikat organik dari Inofice. Pengolahan tanah, baik pembajakan kasar (Sunda: nyingkal, ngawuluku) dan pembajakan halus (Sunda: ngagaru) dilakukan 2 kali. Setelah selesai, kemudian sawah digenangi dengan air selama 1 hari kemudian dibuat laritan (Sunda: bedangan) untuk mengatur jarak tanam.

\section{Penanaman}

Tanam serempak itulah yang dilakukan oleh petani yang tergabung di Kelompok Tani Sarinah. Hal ini dilakukan untuk menjaga serangan hama, dan panen tidak terlalu berbeda. Penanaman dilakukan setelah benih berumur antara 7-12 hari. Jumlah benih yang ditanam antara 1 sampai dengan 2 butir/ batang, untuk menjaga penumpukan. Menurut petani dengan menanam 1 atau 2 biji anakan akan lebih bagus, dan kondisi tanaman akan sehat. Jarak tanam yang digunakan bergantung kebutuhan (dapat 
$25 \times 25 \mathrm{~cm}$, atau $30 \times 30 \mathrm{~cm}$ ), tetapi umumnya jarak tanam yang dilakukan petani yaitu $25 \times 25$ $\mathrm{cm}$ dengan cara tanam legowo. Dengan demikian penyinaran akan terpenuhi.

\section{Perawatan dan Pemupukan}

Perawatan dilakukan hampir setiap hari selama 60 hari, yang diawali dari penanaman kondisi air macak-macak sampai anakan sekitar 10-14 hari; selanjutnya sawah diairi sampai menutup tanah, atau tanah tidak langsung tersinari matahari, agar gulma tidak tumbuh. Setelah betul-betul tidak terlihat pertumbuhan gulma, baru dilakukan pemupukan, sawah dalam keadaan kering. Ketika mulai berbunga (umur 2 bulan) sawah digenangi air, dan sebelum panen baru dikeringkan. Pemupukan yang dilakukan petani yaitu pada saat sebelum tanam (waktu pengolahan), dan setelah tanam umur di atas 14 hari. Untuk 1 hektar sawah diawal dapat menggunakan 6 ton pupuk organik, sehingga petani untuk luas garapannya rata-rata $0,5 \mathrm{Ha}$, menggunakan 3 ton pupuk, yang diperoleh dari ketua kelompok dan dari bantuan dinas pertanian kabupaten, serta usaha sendiri. Pemupukan pada tanam berikutnya akan berkurang jumlahnya. Untuk memenuhi kebutuhan pupuk, periode tanam yang akan datang, biasanya petani menabung pupuk dari kotoran ternak sendiri yang sudah dicampur dengan sampah dan potongan jerami. Artinya petani sudah mampu membuat pupuk organik untuk kepentingan sendiri.

\section{Pengendalian hama penyakit}

Untuk menghidari serangan hama penyakit biasanya petani akan menyemprot tanamannya dengan insektisida hayati, yang dibuat dari berbagai jenis tanaman yang tidak disenangi binatang atau hama seperti nenas, bawang putih, kipait, gadung, daun sirsak dan lain sebagainya. Untuk memenuhi kebutuhan insektisida hayati tersebut, biasanya ketua kelompok sudah menyiapkannya. Ramuan itu dibuat oleh ketua kelompok sendiri, sehingga petani anggota tinggal menggunakan saja. Penyemprotan dilakukan 2 sampai dengan 3 kali, untuk menghindari terjadinya serangan hama dan penyakit.

Kemampuan petani dalam menerapkan prinsip-prinsip SRI ini tidak lepas dari peran agen pembaharu dan ketua kelompok itu sendiri, sehingga mereka muncul menjadi petani cerdas. ini salah satu gambaran dari wujud petani yang berdaya.
Wujud konkrit dari penerapan SRI yang dilakukan oleh anggota Kelompok Tani Sarinah, yaitu dengan melihat produksi hasil panen usahataninya. Dari hasil penelusuran, produktivitas hasil usahatani padi di lokasi penelitian mencapai 6 ton/ha gabah kering panen, atau sekitar 5.1 ton gabah kering giling. Hasil tersebut dibagi dua dengan pemilik setelah dikurangi biaya-biaya termasuk untuk pupuk bila terjadi kekurangan dan atau pinjaman yang dijanjikan akan dibayar pada saat panen.

Kemampuan lain yang harus dimiliki petani yaitu kemampuan ekonomi, terkait kemampuan memupuk modal, dan menjaga kesinambungan pasar. Dalam hal ini petani akan bertahan dan berkembang kehidupannya dengan bertumpu pada sektor pertanian, artinya petani berinovasi, dan berkreasi menjadikan usahataninya sebagai penghasilan utama. Itulah yang dilakukan petani anggota Kelompok Tani Sarinah. Petani yang demikian Soewardi (2005) menyebutnya petani yang memiliki karsa kuat dan David Mc Clelland menyebutnya orang yang memiliki Need for Achievement (N-Ach) yang tinggi.

Lebih lanjut, untuk menjaga kesinambungan usahataninya, para petani anggota yang umumnya menggarap kurang lebih $0,5 \mathrm{Ha}$ (status petani sebagai penggarap), setiap panen mereka tidak langsung menjual, tetapi dijual dalam keadaan kering. Dari jumlah 2,5 ton yang diperolehnya, petani hanya menyisihkan $3 \mathrm{kw}$ padi untuk keperluan makan, selama satu musim, dan sisanya (kurang lebih 1.5 ton padi kering giling) dijual ke ketua kelompok seharga Rp 6.000/kg. Dari hasil penjualan tersebut petani masih dapat menyisihkan uangnya dalam bentuk tabungan melalui arisan sebanyak Rp 3.000.000/musim, yang digunakan untuk perbaikan rumah/ membangun rumah, keperluan lainnya seperti belanja kebutuhan sekunder, dan sisa yang lain digunakan untuk modal menggarap lahan.

Keuletan petani tidak hanya ditunjukkan melalui menabung dalam bentuk uang, tetapi merekapun hampir semua memiliki ternak, yang dibeli dari hasil penjualan gabah. Ternak ini menurut mereka selain sebagai tabungan juga sebagai penghasil pupuk yang akan digunakan di sawah garapannya. Kategori petani demikian yang oleh Max Weber disebut sebagai petani yang baik, yaitu petani yang disiplin, bekerja keras dan berupaya menyisihkan dari sebagian hasilnya dalam bentuk tabungan. 
Secara umum petani penggarap yang berafiliasi dalam Kelompok Tani Sarinah, secara teknis ditunjukan dengan produksinya yang tinggi, dan secara ekonomis memiliki kemampuan menabung, atau menyisihkan bagian keuntungannya untuk modal, dalam hal ini petani sudah memperlihatkan naluri bisnis yang baik (better business), dalam meniju kehidupan yang lebih baik (better living).

Secara sosial petani anggota Kelompok Tani Sarinah semuanya (100\%) memiliki status sebagai petani penggarap, dimana hubungan antara ketua kelompok dengan anggota menunjukkan hubungan kekeluargaan (famili). Hubungan ini sudah terjalin cukup lama, yang dibangun oleh kakek nenek pemilik lahan dengan kakek nenek penggarap lahan. Meski demikian, hubungan patron-client yang terjadi saat ini sudah sangat berbeda dengan apa yang pernah dilakukan oleh nenek moyangnya, Geertz, Herman Soewardi dan Rusidi, menyebutnya sudah terjadi erosi sosial. Hubungan yang terjadi sudah mengarah ke hubungan tidak lagi semata-mata karena hubungan emosional, tetapi memiliki pula hubungan fungsional. Alasan pertukaran $(\mathrm{R}>\mathrm{C})$ seperti yang disampaikan oleh Kelley T, mengikat kuat hubungan antara patron-client dalam pemenuhan kebutuhannya. Dalam hal ini client sangat tergantung kepada ketua kelompok yang juga berposisi sebagai patron, Bagi client, usahatani dengan menggarap lahan kelurga ketua kelompok merupakan satu-satunya mata pencaharian dalam rangka memenuhi kebutuhan hidupnya. Begitu pula bagi patron, client adalah sumber tenaga kerja yang sudah sangat jelas loyalitasnya (memiliki komitmen tinggi). Adanya hubungan yang sudah relatif lama, yang sudah dibangun sejak kakek neneknya, telah menumbuhkembangkan kesamaan pandangan bahwa keluarga tersebut baik patron, maupun client menempatkan sektor pertanian sebagai alternative utama mata pencaharian dalam pemenuhan kebutuhannya. Nucomb dalam Johnson (1992) menyebutnya telah terjadi keseimbangan nilai (balance). Terlebih secara lokasi tempat tinggal/domisili mereka tidak terlalu berjauhan, dimana perumahan berada di sekitar pesawahan. Adanya ketiga hal tersebut telah membangun solidaritas diantara pelaku baik sebagai patron, maupun sebagai client. Kondisi ini secara sosial, telah membangun kemampuan dan kesanggupan petani untuk menjaga kuantitas, dan kualitas produk usahataninya sedemikian rupa sehingga usaha terus berlanjut.
Kemampuan dan kesanggupan yang juga sangat besar dukungannya terhadap keberlanjutan usaha yaitu aspek psikologis. Usahatani padi dengan menggunakan sistem organik murni sangat memerlukan ketelatenan, persaingan gulma dengan tanaman yang dipelihara sangat tinggi, sehingga waktu yang biasa petani gunakan untuk bekerja diluar usahatani setelah tanam, terpaksa mereka gunakan untuk memelihara tanaman, pada gilirannya petani kehilangan pendapatan dari luar usahatani selama 60 hari. Seperti yang diutarakan oleh petani “... kawitanmah renced $P a$, nya kedah nyiapkeun pupuk kanggo kapayun, teras salami 60 dinten kedah ngalongokan sawah bilih binih dilodok meri, oge jukut gancang jaradi, tapi lami-lamimah biasa...." (Awalnya ribet selain harus menyiapkan pupuk untuk tanam yang akan datang, juga harus tiap hari ngontrol ke sawah, takut benih dimakan bebek, dan rumput banyak yang tumbuh, tapi lama-lama kegiatan itu menjadi biasa). Hal lain yang pernah membuat petani tidak semangat yaitu produksinya yang rendah, seperti yang dituturkanya “...ngawitan mah Pa, kesel dunungan paheut sareng ketua kelompok kanggo melakan sawahna ngangge cara organik, ari hasilna malah turun, ari bade dileupaskeun teu aya deui pacabakan, sareng teu gaduh kaahlian, tapi dikeureuyeuh we alhamdulillah lami-lami karaos hasilna..." (Awalnya Pa, kesel juga yang punya lahan dengan ketua sepakat untuk menanami lahannya dengan padi cara organik, karena hasilnya turun, sedangkan untuk bekerja diluar usahatani tidak ada yang bisa dikerjakan, terlebih tidak punya keahlian khusus, tapi Alhamdulillah lama-kelamaan hasilnya sudah terasa).

Proses/kegiatan ini telah membangun keinginan petani menjadi lebih kreatif, apalagi ketika hasil yang diperoleh relatif lebih baik karena harga padinya relatif lebih mahal dari padi biasa. Kalau padi biasa untuk saat ini kering giling seharga Rp 5.200, untuk padi organik ketua kelompok membeli seharga Rp 6.000. Petani tidak lagi merasa puas dengan hasil yang diperoleh (fatalism) mereka terus berjuang untuk meningkatkan produksi usahataninya, hal ini terbukti ketika produksi padinya bisa menyamai produksi padi non organik, yaitu 4,5 sampai dengan 5 ton/ha, gabah kering panen, mereka terus berupaya, sehingga bisa mencapai 6 ton/Ha seperti sekarang ini (melebihi produktivitas padi non organik). 
Dari semua gambaran yang menyangkut keberdayaan petani, mulai dari aspek teknis, ekonomis, sosial dan psikologis, menarik untuk dikombinasikan. Secara umum keberdayaan yang di dalamnya menyangkut kemampuan, kesanggupan dan komitmen, untuk keempat aspek tadi (teknis, ekonomis, sosial dan psikologis) apabila di kombinasikan untuk setiap petani akan menghasilkan 8 kombinasi (Tabel 3).

Tabel 3. Kombinasi Keberdayaan Secara Umum

\begin{tabular}{ccccc}
\hline $\begin{array}{c}\text { Kombi- } \\
\text { nasi ke }\end{array}$ & Mampu & Sanggup & Komitmen & Keterangan \\
\hline 1 & + & + & + & $(3+)$ \\
2 & + & + & - & $(2+)(1-)$ \\
3 & + & - & + & $(2+)(1-)$ \\
4 & + & - & - & $(1+)(2-)$ \\
5 & - & + & + & $(1-)(2+)$ \\
6 & - & + & - & $(2-)(1+)$ \\
7 & - & - & + & $(2-)(1+)$ \\
8 & - & - & - & $(3-)$ \\
\hline
\end{tabular}

Kombinasi tersebut menggambarkan kekuatan dan kelemahan keberdayaan petani dalam mengembangkan padi organik menuju pasar terstruktur. Untuk petani yang tergabung dalam Kelompok Tani Sarinah, dalam upaya memenuhi pasar tersebut baik secara kuantitas, kualitas, maupun kontinuitas sangat tergantung kepada ketua kelompok. Petani menyadari untuk urusan pasar berada pada wilayah ketua kelompok, karena ketua kelompok yang memahami betul tentang peluang pasar, sedangkan untuk urusan produk ada pada wilayah petani dibawah komando dan atau arahan dari ketua kelompok. Secara teknis petani yang tergabung dalam Kelompok Tani Sarinah mulai dari pembenihan, pengolahan tanah, penanaman, pemeliharaan dan panen, petani memiliki kemampuan dan kesanggupan serta komitmen yang tinggi.

Secara ekonomis memberikan indikasi tidak semua petani mampu, tapi masih terdapat petani yang belum mampu untuk menyediakan modal usahatani, tetapi mereka sanggup untuk mengadakan modal tersebut, baik meminjam dari ketua atau menabung dari hasil usahatani. Dari hasil penelusuran, untuk penyediaan pupuk, adakalanya sebagian anggota menggunakan pupuk yang dibuat oleh ketua dan diperhitungkan ketika panen. Namun demikian secara umum petani tetap komitmen untuk mengadakan atau menyisihkan dana dalam pengembangan usahataninya.
Indikasi tidak dicabutnya lahan garapan oleh pemilik (keluarga ketua kelompok) merupakan wujud kemampuan petani secara sosial untuk menjaga kepercayaan pemilik dan ketua kelompok. Melalui kerjasama diantara petani dalam meningkatkan kuantitas dan kualitas produksi mereka meyakinkan ketua bahwa mereka bisa kerjasama dengan kelompok atau ketua kelompok sehingga kebutuhan pasar relatif terpenuhi.

\section{Panen}

Panen merupakan proses memungut hasil yang dilakukan oleh petani dari kegiatan usahataninya. Ke 32 orang anggota kelompok tani sarinah sepakat untuk tidak melakukan panen serempak, setidaknya dibuat 3 kelompok, karena keterbatasan tenaga dan tempat. Setelah dipanen petani tidak langsung menjual gabahnya, tetapi terlebih dahulu dilakukan proses penjemuran. Sehingga mereka menjual gabah dalam keadaan kering giling.

Kemampuan dan kesanggupan petani anggota Kelompok Tani Sarinah, baik secara teknik, sosial, ekonomi maupun psikologis, mengindikasikan bahwa petani tersebut cukup berdaya dalam memasuki kapitalisasi pertanian yang bersinergi dengan lingkungan dan berorientasi keberlanjutan untuk memenuhi pasar terstruktur. Petani tersebut, dengan berbekal kedisiplinan, kejujuran dan kesiapan menghadapi resiko, serta bekerja keras terus menjaga komitmen untuk tetap memenuhi permintaan pasar, merupakan langkah yang tepat di era tingginya persaingan. Petani yang demikian merupakan refleksi dari petani yang berdaya.

\section{KESIMPULAN}

Dari hasil penelitian dapat disimpulkan sebagai berikut : (1) Kelompok Tani Sarinah 100 $\%$ anggotanya adalah petani penggarap, dan tumbuh kembang menjadi kelompok tani padi organik diinisiasi oleh keluarga pemilik lahan dengan adanya stimulasi dari pemerintah; (2) Untuk menjaga kuantitas, kualitas dan kontinuitas usaha, Kelompok Tani Sarinah bermitra dengan kelompok tani mitra dan bermitra dengan pasar terstruktur; (3) Secara umum petani anggota kelompok tani sarinah masuk dalam katagori berdaya, secara teknis produktivitas mampu mencapai 8,7 ton/ha, secara sosial mampu menjaga jejaring, secara ekonomis, mampu dan sanggup memenuhi modal, dan secara psikologis, memiliki kemampuan melihat peluang pasar. 


\section{DAFTAR PUSTAKA}

Alfitri. 2011. Community Development, Teori dan Aplikasi. Pustaka Pelajar. Yogyakarta

Conyers, Diana. 1974. Perencanaan Sosial di Dunia Ketiga Suatu Pengantar. Gajahmada University Press. Yogyakarta

Hasansulama, Imang. 2005. Petani dan Penyuluh Pertanian Manusia Cerdas. Orasi Ilmiah Purnabakti. Universitas Padjadjaran. Bandung Johnson, Doyle Paul. 1992. Teori Sosiologi Klasik dan Modern. Jilid 2. Terjemahan Robert M. Z. Lawang. Gramedia. Jakarta.

Nazir, M. 2003. Metode Penelitian. Ghalia Indonesia. Jakarta

Rusidi. 1993. Pedoman Penelitian dan Penulisan Karya Ilmiah. UPT Penerbitan IKOPIN. Sumedang

Setiawan, Iwan. 2012. Dinamika Pemberdayaan Petani Sebuah Refleksi dan Generalisasi Kasus di Jawa Barat, Widia Padjadjaran. Bandung

Soewardi, Herman. 2005. Nalar, Kontemplasi dan Realita. Bakti Mandiri. Bandung

Styger, Erika. 2011. SRI 2.0: How is the System of Rice Intensification Evolving and What are We Learning?. CIIFAD Seminar. Cornell University

Sugiyono. 2012. Metode Penelitian Kuantitatif Kualitatif dan $R \& D$. CV Alfabeta. Bandung

Sukayat, Yayat, Dika Supyandi, Dhany Esperanza, Ahmad Choibar Tridakusumah. 2013. Rekayasa Model Pemberdayaan Untuk meningkatkan Daya Saing Rantai Pasok Padi Organik yang Berorientasi Pasar Global. Laporan Penelitian PUPT Universitas Padjadjaran. Bandung

Sukayat, Yayat, Dika Supyandi, Dhany Esperanza. 2014. Memastikan Keterlibatan Petani dalam Pengembangan Agribisnis (Studi Kasus Petani Padi Organik di Kecamatan Bojongsoang, Kabupaten Bandung, Jawa Barat). Prosiding Semnas "Pembangunan Inklusif di Sektor Pertanian. Universitas Padjadjaran. Bandung

Sunyoto. Usman. 2003. Pembangunan dan Pemberdayaan Masyarakat. Pustaka Pelajar Yogyakarta

Syahyuti. 2006. 30 Konsep Penting dalam Pemberdayaan Perdesaan Pertanian. Bina Rina Pariwara 